
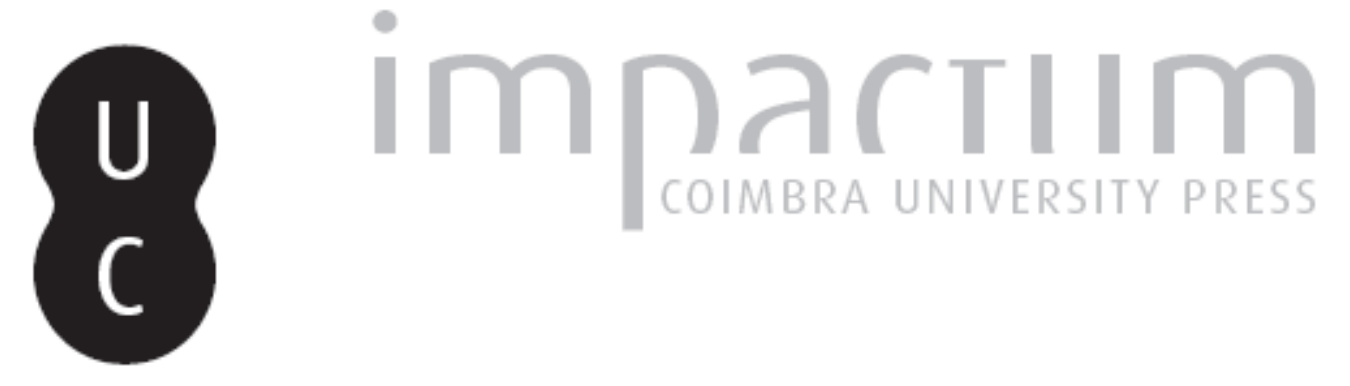

\title{
The role of stereometry in Plato's Republic
}

\author{
Autor(es): Izumi, Chiye
}

Publicado por: Imprensa da Universidade de Coimbra

URL persistente: URI:http://hdl.handle.net/10316.2/42189

DOI: DOl:https://doi.org/10.14195/2183-4105_11_10

Accessed : $\quad$ 26-Apr-2023 13:25:53

A navegação consulta e descarregamento dos títulos inseridos nas Bibliotecas Digitais UC Digitalis, UC Pombalina e UC Impactum, pressupõem a aceitação plena e sem reservas dos Termos e Condições de Uso destas Bibliotecas Digitais, disponíveis em https://digitalis.uc.pt/pt-pt/termos.

Conforme exposto nos referidos Termos e Condições de Uso, o descarregamento de títulos de acesso restrito requer uma licença válida de autorização devendo o utilizador aceder ao(s) documento(s) a partir de um endereço de IP da instituição detentora da supramencionada licença.

Ao utilizador é apenas permitido o descarregamento para uso pessoal, pelo que o emprego do(s) título(s) descarregado(s) para outro fim, designadamente comercial, carece de autorização do respetivo autor ou editor da obra.

Na medida em que todas as obras da UC Digitalis se encontram protegidas pelo Código do Direito de Autor e Direitos Conexos e demais legislação aplicável, toda a cópia, parcial ou total, deste documento, nos casos em que é legalmente admitida, deverá conter ou fazer-se acompanhar por este aviso.

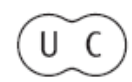




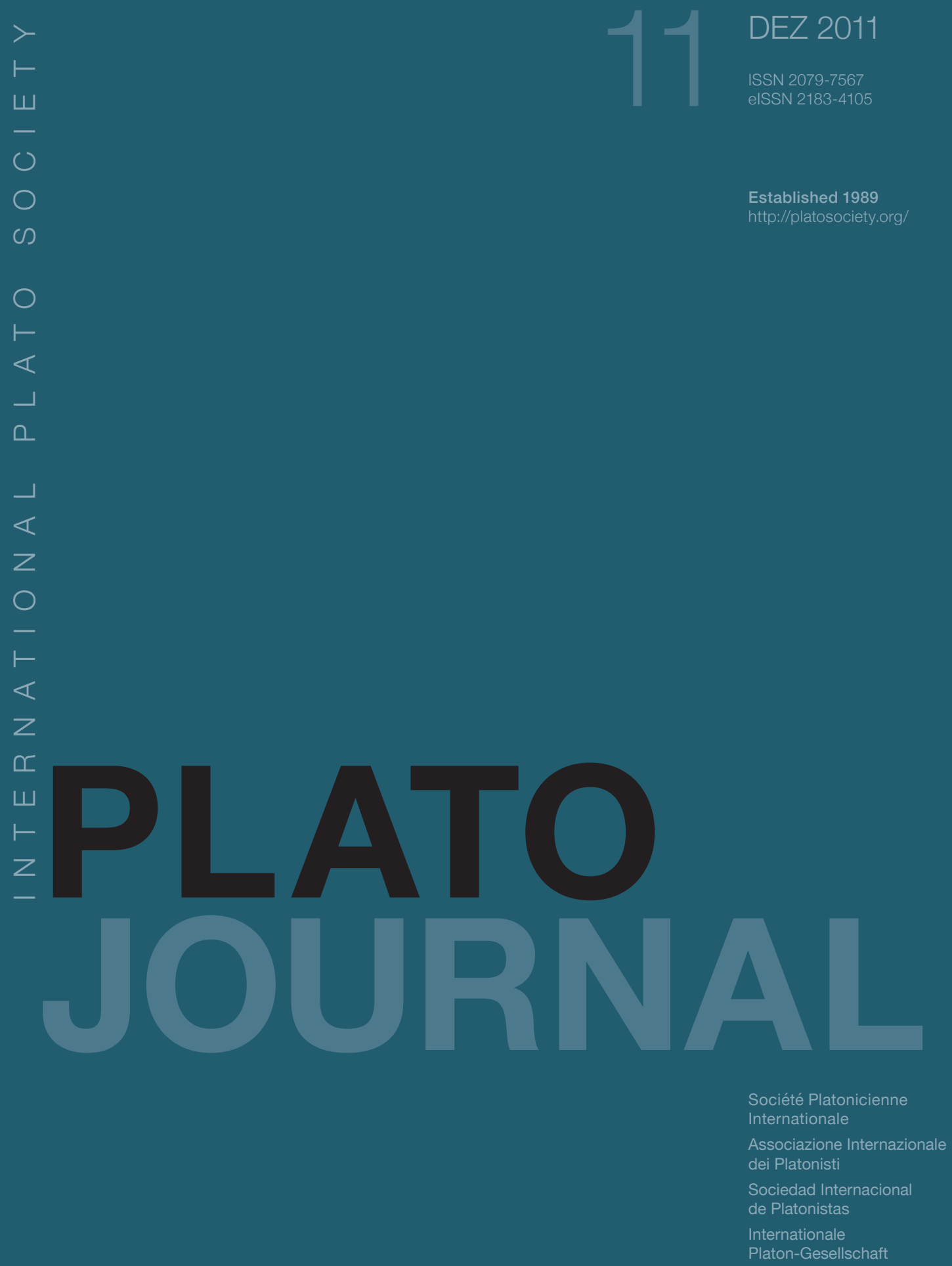




\title{
THE ROLE OF STEREOMETRY IN PLATO'S REPUBLIC
}

\author{
Chiye Izumi (Chiba University)
}

It is in the Republic that stereometry is referred to as one of the mathematical subjects which constitute the prelude for philosophical dialectic. Plato provides stereometry with a number of remarks which need careful investigation. Some of these can be taken as eulogies on stereometry: its marvellous growth (Rep.528c3); its inherent charm (Rep.528c7); its usefulness for contemplating an unchanging reality (Rep.528c5-6). The other remarks, however, relate to stereometry's handicaps: its being dishonoured by cities (Rep.528b6); its difficulty as a subject (Rep.528b6); the lack of a director for the study of stereometry (Rep.528b7); the arrogant investigators of stereometry who do not want to obey the director's advice (Rep.528c1); its being held in contempt by the majority of people (Rep.528c4); its being inappropriately investigated by researchers who are unable to give an account of its usefulness (Rep.528c5-6). It is striking that Plato does not straightforwardly give stereometry the kind of eulogy that he usually bestows upon mathemata, (cf. 'the subject is essential, since it apparently forces the soul to rely purely on the intelligible and to aim for truth in itself $^{1}$ ). Instead he ascribes to it a character less deserving of eulogy. Moreover, it seems worth noting here that Plato seldom provides such specific details concerning other particular branches of mathematics. Therefore, one of the attempts which will be made in this paper is to investigate those puzzling points for clues as to a particular attitude Plato might have taken towards stereometry upon his encounter with it.

We also need to pay attention to the fact that Plato deliberately interpolates stereometry between geometry and astronomy, and emphasises both the independence of stereometry from geometry and the correlation of stereometry with astronomy. In the Republic, we see clearly that stereometry is restricted to the investigation into 'the third growth' (528b2), or 'solid' $528 \mathrm{~b} 1)$, or 'the growth into cubes and whatever shares in depth'( $528 \mathrm{~b} 3,528 \mathrm{~d} 8)$, while geometry

\footnotetext{
${ }^{1}$ As for the eulogy given to arithmetic, see, Rep.525b1, 525c4-6, 526b1-3. For geometry, see, Rep.526e1, 527b9-11.
}

PLATO, The electronic Journal of the International Plato Society, n 11, 2011.

http://gramata.univ-paris1.fr/Plato/article102.html

(c) All rights of reproduction of any form reserved. 
is restricted in the passage to the study of 'the second growth' (528b2) or 'plane' (528d2-3). Astronomy which follows stereometry is defined as the study of 'revolving solids' (528a9-b1, 528e1). Why does Plato distinguish stereometry from geometry?

\section{Republic 528b4-5}

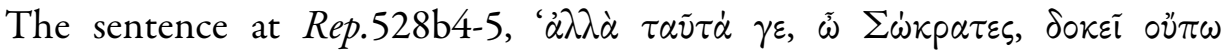

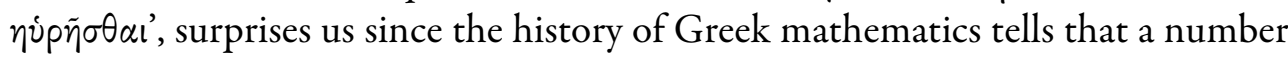
of great contributions to stereometry were made in the fifth and fourth centuries B.C. Although it is almost impossible to find credible evidence concerning the chronological date and year of each contribution to stereometry within the range of an allowable error of five to ten years, we might recall Hippocrates of Chios, Democritus, Archytas, Theaetetus, and Eudoxus; it is certain that Plato associated with some of these figures. Nevertheless, he writes ' $\dot{\alpha} \lambda \lambda \dot{\alpha} \tau \alpha \tilde{\nu} \tau \dot{\alpha} \gamma \varepsilon$, $\tilde{\omega}$

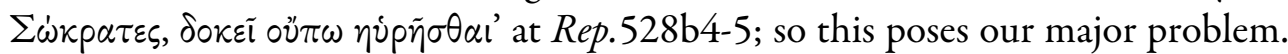
In considering what may lie behind the sentence, I shall begin by re-assessing what is indicated by the pronoun ' $\tau \alpha \tilde{\nu} \tau \alpha$ ' at Rep.528b4. This pronoun is usually taken to indicate 'this subject', namely stereometry in general, so that the sentence translates as: 'this subject [stereometry], Socrates, does not appear to have been investigated yet'. ${ }^{2}$ However, this translation would be in tension with that state of affairs in which a number of great contributions to stereometry were already made in the fifth and fourth centuries B.C. Shorey says: 'this [translation] is not to be pressed. Plato means only that the progress of solid geometry is unsatisfactory. ${ }^{3}$ Adam also warns: 'Plato does not of course mean to say that the study of stereometry had not yet been invented. He only means that its problems had not yet been "discovered" or "resolved" '. ${ }^{4}$ Although these views are worth heeding, it should be noted that the pronoun ' $\tau \alpha \tilde{\tau} \tau \alpha$ ' at Rep.528b4, i.e. 'what had not yet been investigated', is not necessarily identified with 'this subject' i.e. stereometry: neither the generic term 'stereometry ( $\sigma \tau \varepsilon \rho \varepsilon о \mu \varepsilon \tau p i \alpha)$ ' nor the word 'the subject $(\tau \dot{o} \mu \dot{\alpha} \theta \eta \mu \alpha)$ ' appears in the context immediately surrounding the

\footnotetext{
2 This is of Shorey's translation (1935). Grube (1992): 'this subject hasn't been developed yet.'

${ }^{3}$ Shorey 1935: 528 n. a.

${ }^{4}$ Adam 1902: vol.2. 122.
}

PLATO, The electronic Journal of the International Plato Society, n 11, 2011.

http://gramata.univ-paris1.fr/Plato/article102.html

(c) All rights of reproduction of any form reserved. 
sentence. We need to specify more clearly what is indicated by the pronoun ' $\tau \alpha \tilde{\nu} \tau \alpha$ ' at Rep.528b4.

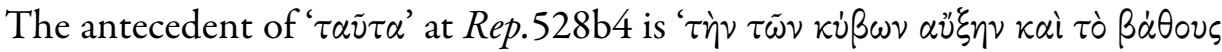
$\mu \varepsilon \tau \dot{\varepsilon} \chi 0 v^{\prime}$ at Rep.528b3, as is clearly indicated by the text itself. The' $\tau \alpha \tilde{\nu} \tau \alpha$ ', accordingly, should be glossed 'the increase of cubes and everything that partakes

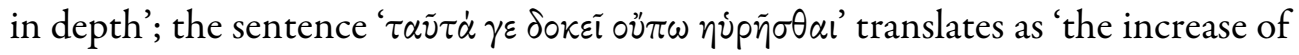
cubes and everything that partakes in depth do not appear to have been investigated yet'. 5 This translation appears redundant, but it provides us with

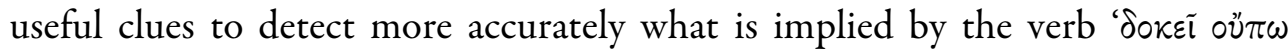

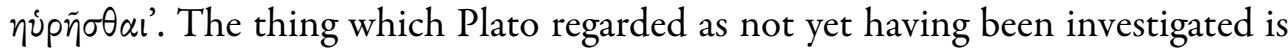
not stereometry in general, but rather, more specifically, the problems concerning 'the growth into cubes and everything that partakes in depth'.

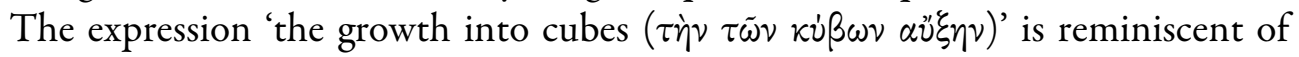
the Delian problem expressed in terms of 'the duplication of the cube

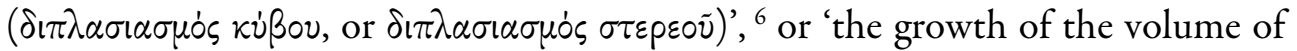

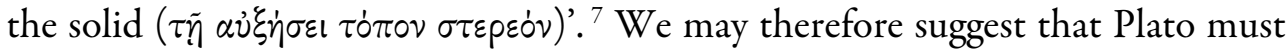
have thought in particular of the problem of the duplication of the cube when he referred to stereometry in the Republic, while the reference to 'everything that partakes in depth' indicates the three-dimensional mathematical solid in general. We may now ask whether these problems had not really been investigated yet, or rather whether, despite these problems having already been investigated, Plato himself judged that they had not, or at least that they had not been investigated in the proper manner. In considering these questions, we recognise that neither the dramatic date of the Republic nor the date of the solution to the problem of the duplication of the cube can be determined accurately.

Clues here seem to be contained in the Republic passage from $528 \mathrm{~b} 6 \mathrm{ff}$. Plato, enumerating the obstacles standing in the way of stereometry (Rep.528b6-c5), writes: 'nevertheless, in spite of all these obstacles, the force of its charm has caused it to develop' (528c6-7). He repeats: 'the subject has outstanding charm' (528d1). Plato's emphasis on the remarkable growth of stereometry, which is clearly indicated by the contrasts between the obstacles and its growth, and his

\footnotetext{
${ }^{5}$ The ' $\gamma \varepsilon$ ' seems to help this line of interpretation. But we should be careful because in a sense stereometry as a whole is in Plato's sights.

${ }^{6}$ DL 8.83; Plutarch Quaest. conv.,VIII. 718e10.

${ }^{7}$ Plutarch De gen. $579 \mathrm{~b} 9$.
}

PLATO, The electronic Journal of the International Plato Society, n 11, 2011. http://gramata.univ-paris1.fr/Plato/article102.html

(c) All rights of reproduction of any form reserved. 


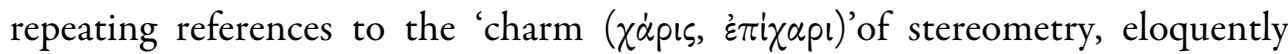
illustrate that stereometry has enjoyed great achievements manifest to everyone. We might therefore suggest a certain tension or ambivalence in Plato's position. On the one hand he does not want to admit that the problems of stereometry have been adequately investigated: on the other he clearly concedes that they have been investigated in a sense.

\section{Plato's attitude towards Archytas' solution to the duplication of the cube}

Why does Plato write that 'the growth into cubes and everything that partakes in depth have not been investigated yet' at Rep.528b4-5, despite the fact that everyone knows of its remarkable achievements and growth? What kind of

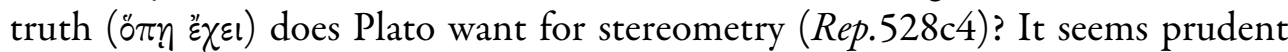
here to survey briefly the development of the use of tools for geometrical construction. Eratosthenes, who developed the solution to the problem of the duplication of the cube, boasts thus: 'an easy mechanical solution [to the problem of the duplication of the cube] was found by me, and by means of it I will find, not only two means to the given straight lines, but as many as may be enjoyed'(Eutocius 88.4-90). The instrument is also called 'mesolabe', meanmaker, for finding the mean proportionals. ${ }^{8}$ We may recognise, surmising from Eratosthenes' depiction of his tool, that the use of tools in geometrical construction later developed in a direction opposed to Platonic mathematics which aims to draw the soul from the sensible towards the intelligible realm. In the case of Eratosthenes, it is the instrument that mechanically solves the problem of the duplication of the cube; the Platonic tool for mathematics, that is, a

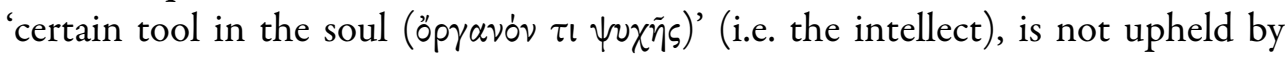
Eratosthenes. We may also imagine that Alexandrian mathematicians surrounding Eratosthenes were occupied with inventing and using mechanical tools for geometrical construction. ${ }^{9}$ They do not seem to have been concerned with Platonic mathematics which draws the soul from the sensible to intelligible

${ }^{8}$ See also Vitruvius. IX Prooem.

${ }^{9}$ As one of the examples of such mathematicians, we may refer to Nicomedes, who uses, according to Eutocius (98.1-7), 'mechanical tool' in solving the problem of the duplication of the cube. Nicomedes solved the problem by means of the concoid and proved that 'the curve can be described mechanically'. See, Pappus Coll. iv. 26. 27.

PLATO, The electronic Journal of the International Plato Society, n 11, 2011.

http://gramata.univ-paris1.fr/Plato/article102.html

(c) All rights of reproduction of any form reserved. 
realm; the value of geometry for them lies not in the use of the tool in the soul but instead in the use of the mechanical tools for solving the geometrical problem.

If we take into consideration the Eratosthenean terminus of the development of the use of mathematical tools, we might be able to understand why Plato reproached Archytas et al. for having used instruments for solving the problem of the duplication of the cube. Plato's reproach to Archytas et al. can be taken as a warning that mathematicians should not be distracted by their interest in developing more sophisticated tools from the proper study of geometry itself. Plutarch reports: 'Archytas et al. set out to remove the problem of doubling the cube into the realm of instruments and mechanical devices.' (Quaest. conv.718e); 'Plato inveighed against them as corrupters and destroyers of the pure excellence of geometry, which thus turned her back upon the incorporeal things of abstract thought and descended to the things of sense, making use, moreover, of objects which required much mean and manual labour'(Marcellus 14). Thus, Plutarch clearly tells that Plato's rebuke for Archytas et al. stems not merely from their use of tools but rather from both their disregard of the intelligible realm and the confining themselves to a concern with the use of tools. It is in this respect that Plutarch's reports should be appreciated, and we must not exaggerate the superficial point that Plato reproaches mathematicians only for their use of tools. Archytas might have used not only the compass and ruler but also a certain model of a three-dimensional mathematical object, but it must be emphasised that due to a lack of evidence it is very hard to say exactly what kind of instrumental and mechanical devices were actually used for the study of stereometry in Plato's time. Nevertheless, it seems worth considering here a mechanical solution which Eutocius ascribes to Plato himself. Eutocius (56. 13-58. 14) writes that: 'Plato used carpenter's squares with grooves and adjustable rulers' in solving the problem of the duplication of the cube, although no historians of Greek mathematics believe this. However, if we construe the solution ascribed to Plato as a type of solution current in Plato's time, we might suggest that the study of stereometry was, in a sense, a study of mechanical instruments. Although Plato expected stereometry to rid itself of reliance upon the mechanical tools (opprava $\mu \eta \chi \alpha \nu i k \dot{\alpha})$ and to be metamorphosed into the Platonic stereometry using the tool in the soul (öpyavóv $\tau \iota \psi v \times \tilde{\eta} s),{ }^{10}$ practical and/ or mechanical investigations of

\footnotetext{
${ }^{10} \mathrm{I}$ suggest that 'it is the tool in the soul that which sees truth' at Rep.527e might be an euphemical allusion to the current method of stereometry using the mechanical tools.
}

PLATO, The electronic Journal of the International Plato Society, n 11, 2011. http://gramata.univ-paris1.fr/Plato/article102.html

(c) All rights of reproduction of any form reserved. 
such problems as the duplication of the cube distract stereometricians from the proper study of their subject matter. ${ }^{11}$

\section{Who are the researchers of stereometry that Plato bears in mind at Rep. 528b-c?}

The argument so far may suggest that Plato, when writing the passage (Rep.528b-c), might have kept in mind those mathematicians concerned in particular with the problem of the duplication of the cube; they include, according to Plutarch's testimonies, Archytas, Eudoxus and perhaps Menaechmus and Helicon. However, we know that there are other candidates whom Plato might think of; for example, as mentioned before, there are Hippocrates of Chios, Democritus, Theodorus, and Theaetetus. It does not seem that all of them contributed to the solutions to the problem of the duplication of the cube, but some of them dealt with the problem and others could inquire into, to use Plato's phrase, 'everything that partakes in depth' (Rep.529b3). Obviously we cannot attempt to be too specific about who precisely Plato has in mind, but it seems unlikely that he has stereometricians in general in view. This is because he gives precise characterizations of the researchers in question and of the circumstances of their work. I turn now to evaluate this important evidence.

Let us consider the following points from the Republic passage (528b-c): (1) no city holds stereometry in honour; (2) the lack of a director for the study of stereometry; (3) the researchers of stereometry are arrogant; (4) they are ignorant of the usefulness of stereometry. I would point out an interesting coincidence that two of the circumstances surrounding stereometry in the Republic (its being disregarded by cities and its lack of a director) appear in Aristoxenus' description of the circumstances surrounding the Pythagoreans who survived Cylon's rebellion. ${ }^{12}$ It seems unlikely that Aristoxenus means to recall the description of stereometry in the Republic in the above passage. But we might speculate that the two points appearing in both Plato and Aristoxenus might have been regarded as a topos of the Pythagoreans. If so, the researchers of stereometry in the Republic

${ }^{11}$ At Rep.527e1-2, Plato mentions: 'the instrument in the soul has been destroyed and blinded by our ordinary pursuits'. Although this statement is not directly addressed to the study of stereometry, it seems worth noting here.

${ }^{12}$ Iamblichus, VP. 250. As for Cylon's rebellion, see also Burkert 1972: $115 \mathrm{ff}$.

PLATO, The electronic Journal of the International Plato Society, n 11, 2011.

http://gramata.univ-paris1.fr/Plato/article102.html

(c) All rights of reproduction of any form reserved. 
could include Pythagorean refugees from Southern Italy, though this would be a bold conjecture. ${ }^{13}$

\section{The role of stereometry in Plato's educational programme}

Despite the obstacles accompanying stereometry, why would Plato introduce stereometry into the educational programme of the candidate for philosopherking? The introduction of stereometry into the framework of the mathemata, I suggest, is motivated by the consideration of the ontological sequence of mathematical objects. Now we may ask why such a rationale for the order of the mathemata is necessary. It is strongly claimed that apprehending the kinship of the mathemata is a necessary condition for becoming a philosopher-king (Rep.531c9-d4, 537c1-7). Therefore, a rationale for the kinship of the mathemata needs to be prepared, though it is not explained explicitly in the Republic. The rationale seems to be given in terms of the sequence of mathematical objects (number, plane, solid, the movement of solid and of number). We might therefore suggest that the introduction of stereometry into the framework of the mathemata is necessary because it completes the sequence of mathematical objects.

Next we may ask: where does the sequence of the mathematical objects come from? Is the sequence a mere sequence? Or does it have any significant correlation with the essence and order of the universe? It seems that Plato relates the sequence of mathematical objects to the generation of the universe. There are a number of variants of the views that the universe is generated out of the sequence of mathematical objects. Examples include the 'fluxion theory' as it appears in Proclus and the account of the generation of the dimensions as it appears in Nicomachus etc. ${ }^{14}$ These theories may be attributed to Pythagoreans, or to

\footnotetext{
${ }^{13}$ According to von Fritz (1940: 76), 'there was a large emigration of Pythagoreans from Italy... In about 390-350 the so-called Pythagoristai appear in Attic literature.' Although no one has ever tried to find the 'Pythagorean refugees' in the Platonic Corpus, the evidence offered by von Fritz does not rule out a possibility that Plato could allude to them somewhere in his dialogues.
}

${ }^{14}$ Nicomachus of Gerasa, Arithm. II, ch.6-7; Sextus, adv. Math. x, 280, etc.

PLATO, The electronic Journal of the International Plato Society, n 11, 2011.

http://gramata.univ-paris1.fr/Plato/article102.html

(c) All rights of reproduction of any form reserved. 
Xenocrates and his fellow-members of the Academy. ${ }^{15}$ Regardless of whether or not the proper ascription of the theories can be decided, the fact that there are many variants of the doctrine might indicate that serious consideration was given to the problem as it appears in the Republic concerning how the kinship of the mathemata correlates further with the essence of things. In this sense, stereometry dealing with the three-dimensional mathematical object has a particular significance for constructing the theory of the generation of the universe being three-dimensional; we see in the Timaeus stereometry come to the fore in Plato's cosmology.

PLATO, The electronic Journal of the International Plato Society, n 11, 2011.

http://gramata.univ-paris1.fr/Plato/article102.html

(c) All rights of reproduction of any form reserved. 


\section{REFERENCES}

BARker, A. 1994. "Ptolemy's Pythagoreans, Archytas, and Plato's Conception of Mathematics." Phronesis 39: 113-135.

BergGren, J.L. 1991. "The Relation of Greek Spherics to Early Greek Astronomy." In Bowen ed. Science and Philosophy in Classical Greece, London. 227-248.

Bowen, A.C. 1982. "The Foundation of Early Pythagorean Harmonic Science: Archytas, Fragment 1." Ancient Philosophy 2: 79-104.

Bowen, A.C. 1983. "Menaechmus versus the Platonists: Two Theories of Science in the Early Academy." Ancient Philosophy 3:11-21.

Bowen, A.C. 1991. Science and Philosophy in Classical Greece. Lodon.

BUrkert, W. 1972. Lore and Science in Ancient Pythagoreanism. Cambridge, Massachusetts.

BurnYeat, M.F. 2000. "Plato on Why Mathematics is Good for the Soul." In T. Smiley ed. Mathematics and Necessity, Oxford, 1-81.

Cherniss, H. 1951. "Plato as Mathematician.” Review of Metaphysics 4: 395-425.

Cuomo, S. 2001. Ancient Mathematics. London.

FOWLER, D.H. 1987. The Mathematics of Plato's Academy. Oxford.

FRITZ, K. 1940. Pythagorean Politics in Southern Italy. New York.

FRITZ, K. 1970. "The Discovery of Incommensurability by Hippasus of Metapontum." In D. Furley and R. Allen ed. Studies in Presocratic Philosophy vol. 1, 382-412.

HeATH, T. 1921. A History of Greek Mathematics, 2 vols. Oxford.

Huffman, C.1996. Philolaus of Croton. Cambridge.

Huffman, C.2005. Archytas of Tarentum. Cambridge.

IzUmI, C.1999. "The Role of Stereometry in Plato's Thought." Ph.D. Dissertation, University of Cambridge.

KAHN, C. 2001. Pythagoras and the Pythagoreans. Indianapolis.

Koetsier, T. and Bergmans, L. ed. 2005. Mathematics and the Divine. Amsterdam.

KNORR, W.R. 1986. The Ancient Tradition of Geometric Problems. Boston.

MilleR, M.1999. "Figure, Ratio, Form: Plato's Five Mathematical Studies." Apeiron 32:73-88.

LLOYD, G.E.R. 1985-1986. "The Alleged Fallacy of Hippocrates of Chios." Apeiron 20: 103-127.

LLOYD, G.E.R. 1987. The Revolutions of Wisdom. California.

PLATO, The electronic Journal of the International Plato Society, n 11, 2011.

http://gramata.univ-paris1.fr/Plato/article102.html

(c) All rights of reproduction of any form reserved. 
LLOYD, G.E.R. 1990. "Plato and Archytas in the Seventh Letter." Phronesis 35: 159-173.

LLOYD, G.E.R. 1991. Methods and Problems in Greek Science: Selected papers. Cambridge

LlOYD, G.E.R. 1992. "The Meno and the Mysteries of Mathematics." Phronesis 37: $166-183$

Meinwald, C. 2002. "Plato's Pythagoreanism." Ancient Philosophy 22:87-101.

NetZ, R. 2003. "Plato's Mathematical Construction." Classical Quarterly 53:500-509.

Sedley, D.N. 1976. "Epicurus and the Mathematicians of Cyzicus." Cronache Ercolanesi 6:23-54.

Thesleff, H. 1990."Theaitetos and Theodoros." Arctos 24: 147-159.

ZHMUD, L. 1998. "Plato as 'Architect of Science'." Phronesis 43: 211-244.

PLATO, The electronic Journal of the International Plato Society, n 11, 2011.

http://gramata.univ-paris1.fr/Plato/article102.html

(c) All rights of reproduction of any form reserved. 